\title{
PENGARUH PENGGUNAAN SOFTWARE AKUNTANSI SYSTEM APPLICATION AND PRODUCT (SAP) DAN KUALITAS NILAI INFORMASI PELAPORAN KEUANGAN TERHADAP KEPUASAN PENGGUNA SOFTWARE AKUNTANSI (STUDI KASUS PADA PT. PLN (PERSERO) KANTOR WILAYAH ACEH-KOTA BANDA ACEH)
}

\author{
Wahyuddin $^{1}$, Mira Afriani ${ }^{2}$ \\ ${ }^{1,2}$ Prodi Akuntansi Fakultas Ekonomi dan Bisnis Universitas Malikussaleh Lhokseumawe \\ wahyuddin@unimal.ac.id
}

\begin{abstract}
This research aims to know influence of the use of System Application Product and (SAP) accounting software and the quality of financial reporting information value to the satisfaction of the consumers of accounting software. This research use census method and the population is the employees at financial division, HRS\&PUBLIC division, planning and technical field division. The respondents of this research are the employees who apply the accounting software of System Application Product and (SAP) at PT. PLN (PERSERO), Regional Office of AcehBanda Aceh city. The samples were taken using census sampling technique. The data were analysed using multiple linear regression analysis and hypothesis were tested using SPSS 17. The result are as follows: the usage of accounting software of System Application Product and (SAP) has a signifcant effect on the satisfaction of consumer of accounting software, the quality of financial reporting information value has a significant effect on the satisfaction of consumer of accounting software, and the usage of accounting software of System Application Product and (SAP) and quality of financial reporting information value has an significant effect on the satisfaction of consumer of accounting software. The further researcher should change the research variables, research object and use a better tool analysis in order to get more accurate data.
\end{abstract}

Keywords: System Application and Product (SAP), Quality of Financial Reporting Information Value, Satisfaction of Consumer Satisfaction of Accounting Software.

\section{PENDAHULUAN}

Perkembangan sistem informasi di dunia bisnis kini semakin memudahkan organisasi dalam menjalankan bisnisnya. Perkembangan tersebut memaksa organisasi untuk terus mengikuti perkembangan teknologi. Untuk mencapai tujuannya, setiap perusahaan memerlukan sistem yang bisa mengatur semua proses bisnis yang terjadi pada perusahaan. Dari mulai proses transaksi, proses produksi dan lain-lain, hal ini dilakukan untuk mempercepat pekerjaan yang ada di dalam perusahaan tersebut.

PT PLN (PERSERO) merupakan suatu badan milik negara (BUMN) yang bergerak di bidang ketenagalistrikan di Indonesia dan memiliki tanggungjawab besar untuk mampu memberikan pelayanan terbaik kepada masyarakat. PT. PLN (PERSERO) Kantor Wilayah Aceh-Kota Banda Aceh dalam pengolahan datanya atau bukti transaksi menggunakan software SAP (System Application and
Product) dan sudah diresmikan sejak 01.01.2013 di wilayah kerja PT PLN (Persero) wilayah Aceh. Hampir semua bidang di PLN Aceh dapat mengakses SAP, namun yang umumnya menggunakan SAP adalah bidang keuangan, bidang SDM\&umum, bidang perencanaan, dan bidang teknik.

Menurut data hasil wawancara dengan Bapak Jafran karyawan pada bagian SDM\&umum di PT. PLN (PERSERO) Kantor Wilayah Aceh-Kota Banda Aceh pada tanggal 16 Agustus 2018, sistem yang digunakan sebelum menggunakan software SAP (System Application and Product) adalah Sistem Informasi Pegawai (SIPEG) terdapat di di bagian SDM, Sistem Informasi Manajemen Keuangan (SIMKEU) terdapat di bagian keuangan, dan Sistem Material (SIMAT) terdapat di bagian logistik sistemsistem tersebut masih belum bisa terintegrasi dengan pusat, dengan kata lain Sistem Informasi Pegawai ini masih belum terkoneksi dengan kantor pusat, sehingga kantor pusat tidak bisa mengontrol atau mengambil data yang diperlukan secara online, jadi 
ketika akan mengirimkan data harus dilakukan secara manual. Sehingga PT. PLN (PERSERO) Kanwil Aceh-Kota Banda Aceh memutuskan menggunakan software SAP (System Application and Product).

Setelah diterapkannya Sistem Application And product (SAP) di PT PLN (PERSERO) Kantor Wilayah Aceh-Kota Banda Aceh tidak ada kendala yang besar bagi pengguna software, namun hanya perlu pendidikan Software Akuntansi System Applicatios and product (SAP) ini secara berkala, sejalan dengan adanya mutasi dan rotasi pegawai. Namun dengan diterapkannya software ini maka seluruh bidang bekerja sama untuk menunjang kegiatan operasional, sehingga terjadi lalu lintas antar unit PLN tersebut. Terintegrasinya pekerjaan di beberapa bidang menyebabkan kemudahan para pengguna software dalam pengendalian data, satu sumber data, dan tidak berulang beberapa pekerjaan seperti penginputan data. SAP merupakan suatu aplikasi yang menghimpun semua data agar lebih mudah mengontrol data dan pekerjaan, Just in time data, lebih mudah mengelompokkan biaya berdasarkan cost driver, dan terintregrasi ke seluruh PLN se Indonesia. Di bagian payroll, SAP dapat mengakses data penghasilan secara confidential dan mandiri, adanya pengawasan berjenjang sesuai dengan kewenangannya untuk semua modul, pelaporan akuntansi perusahaan juga lebih cepat, detail dan mudah, serta user friendly.

Di dalam perusahaan, sistem informasi yang utama yaitu sistem informasi akuntansi. Sistem Informasi Akuntansi (SIA) adalah suatu sistem informasi yang dirancang untuk menerapkan prinsipprinsip dasar akuntansi dengan tujuan memenuhi kebutuhan perusahaan akan informasi akuntansi.

SAP (system Application and product) adalah Software yang implementasikan konsep ERP (Enterprise Resource Planning) yang merupakan konsep sistem informasi yang mengintegrasikan antara beberapa bagian yang saling berkaitan di sebuah perusahaan. SAP (system Application and product) terdiri dari sejumlah modul yang mempunyai kemampuan mendukung semua transaksi yang perlu dilakukan suatu perusahaan dan setiap aplikasi bekerja secara berkaitan satu dengan yang lainnya.

Informasi yang berkualitas tinggi adalah informasi yang dapat membantu pengguna untuk melakukan tindakan yang di harapkan (James A Hall, 2008). Pengguna membutuhkan informasi yang berkualitas tinggi karena akan meningkatkan nilai keputusan yang akan diambil oleh perusahaan (O'Brien \& Marakas, 2011)

Kepuasan penggunaan merupakan penilaian yang menyangkut apakah kinerja suatu sistem informasi itu relatif bagus atau jelek, dan juga apakah system informasi yang disajikan cocok atau tidak cocok dengan tujuan pemakainya. Jika para pengguna merasa puas dengan sistem informasi yang mereka gunakan, maka dapat dikatakan sistem informasi tersebut dapat dikatakan bekerja dengan baik atau sukses. Dengan kata lain faktor penentu dari kesuksesan suatu sistem informasi adalah rasa puas dari pengguna yang sudah menggunakan sistem informasi tersebut (Lee dan Kim, 2010).

Mutiara (2016) dalam penelitiannya mengenai Pengaruh Kualitas Sistem Informasi, Kualitas Informasi, dan Perceived Usefulness terhadap Kepuasan Pengguna Sistem Informasi Akuntansi. Hasil penelitian secara simultan menunjukkan bahwa variabel Kualitas Sistem Informasi, Kualitas Informasi, dan Perceived Usefulness memiliki pengaruh terhadap Kepuasan Pengguna Sistem Informasi Akuntansi Secara parsial menunjukkan terdapat pengaruh signifikan antara kualitas sistem informasi terhadap kepuasan pengguna sistem informasi akuntansi, kualitas informasi berpengaruh signifikan terhadap kepuasan pengguna sistem informasi akuntansi dan Perceived Usefulness tidak berpengaruh signifikan terhadap kepuasan pengguna sistem informasi akuntansi.

Data yang digunakan untuk penelitian ini adalah data primer. Data primer diperoleh dari penelitian ini berupa opini dari responden yang berbentuk jawaban kuesioner yang dibagikan langsung kepada pengguna software SAP (System Application and Product) pada PT. PLN (PERSERO) Kantor Wilayah Aceh-Kota Banda Aceh. Penelitian ini menggunakan 2 (dua) variabel diantaranya: 2 (dua) variabel independen dan 1 (satu) variabel dependen. Maka dari itu peneliti tertarik meneliti untuk menganalisi dengan variabel diantaranya: SAP (System Application and Product), kualitas nilai informasi pelaporan keuangan, dan kepuasan pengguna software. Penelitian ini mereplikasi dari penelitian sebelumnya dengan waktu dan objek penelitian yang berbeda yaitu PT. PLN (PERSERO) Kantor Wilayah Aceh-Kota Banda Aceh, tahun 2017.

Dari latar belakang yang telah dikemukakan tersebut, penulis tertarik melakukan penelitian dengan judul "Pengaruh Penggunaan Software Akuntansi System Application and Product (SAP) Dan Kualitas Nilai Informasi Pelaporan Keuangan Terhadap Kepuasan Pengguna Software Akuntansi (Studi Kasus Pada PT PLN (Persero) Kantor Wilayah Aceh-Kota Banda Aceh)".

\section{KAJIAN PUSTAKA}

\section{KEPUASAN PENGGUNA SOFTWARE}


Kepuasan dapat diartikan sebagai sesuatu keadaan dalam diri seseorang atau sekelompok orang yang telah berhasil mendapatkan sesuatu yang dibutuhkan dan diinginkannya (Sutardji dan Maulidyah, 2006).

Kepuasan pengguna digunakan secara luas sebagai pengukur keberhasilan sistem informasi (kitcharoen, 2007). Pengguna akhir dapat didefinisikan sebagai pengguna final atau akhir atas suatu yang dimaksud, Seandainya hasil yang diperoleh melebihi harapan, tentu pengguna akan merasa sangat puas (Bergensen, 2008).

Insap Santoso (2009) menyatakan bahwa kepuasan pengguna akhir adalah kepuasan pengguna sistem menunjuk kepada suatu keadaan dimana pengguna merasa puas setelah menggunakan sistem tersebut karena kemudahan yang dimiliki oleh sistem. Dengan kata lain, semakin pengguna menyukai suatu sistem, secara implisit mereka merasa puas dengan sistem yang dibuat.

Menurut DeLone dan McLean (2003), terdapat lima indikator untuk mengukur kepuasan pengguna (user) yaitu sebagai berikut:

1. Content adalah kepuasan pengguna (user) ditinjau dari isi. Isi biasanya berupa fungsi dan modul yang digunakan oleh pengguna dan juga informasi yang dihasilkan yang sesuai dengan kebutuhan pengguna (user).

2. Accuracy adalah kepuasan pengguna (user) dari sisi keakuratan data ketika menerima input kemudian mengolahnya menjadi informasi.

3. Format adalah kepuasan pengguna dilihat dari output yang dihasilkan.

4. Ease of use adalah kepuasan pengguna dari sisi kemudahan pengguna atau user-friendly dalam menggunakan sistem seperti proses memasukkan data, mengolah data, dan mencari informasi yang dibutuhkan.

5. Timerliness adalah kepuasan pengguna dari sisi ketepatan waktu sistem dalam menyajikan atau menyediakan data dan informasi yang dibutuhkan oleh pengguna.

Hubungan System Application and Product (SAP) dan kualitas nilai informasi pelaporan keuangan terhadap kepuasan pengguna software

Kualitas sistem informasi akuntansi secara signifikan akan mempengaruhi kualitas informasi akuntansi. Dalam penelitian ini informasi yang dimaksud adalah laporan keuangan yang akan digunakan baik oleh pihak eksternal maupun internal perusahaan. Hendaknya aplikasi System Application and Product (SAP) yang digunakan mampu menyediakan informasi yang dibutuhkan penggunanya, karena semakin berkualitas laporan keuangan yang dihasilkan, semakin tepat keputusan yang akan diambil perusahaan dan semakin tinggi tingkat kepuasan pengguna akhir software System Application and Product (SAP), maupun juga sebaliknya.

$\mathrm{H}_{1}$ : Penggunaan Software Akuntansi System Application and Product (SAP) dan Kualitas Nilai Informasi Pelaporan Keuangan berpengaruh terhadap Kepuasan Pengguna Software Akuntansi.

\section{SISTEM INFORMASI AKUNTANSI}

Bodnar dan Hopwood (2004) Sistem Informasi Akuntansi adalah kumpulan sumber daya, seperti manusia dan peralatan yang diatur untuk mengubah data keuangan dan data lainnya menjadi informasi. Ada tiga subsistem utama SIA (Sistem Informasi Akuntansi), yaitu:

1. Sistem pemprosesan transaksi, mendukung operasi bisnis setiap hari dengan jumlah dokumen dan pesan-pesan untuk para pemakai seluruh organisasi.

2. Sistem pelaporan keuangan, menghasilkan laporan keuangan seperti laporan laba-rugi, neraca, laporan arus kas, pengambilan pajak, dan laporan-laporan lainnya yang ditetapkan oleh hukum.

3. Pelaporan manajemen, menyediakan laporan keuangan bagi manajemen dengan tujuan khusus dan informasi yang diperlukan untuk mengambil keputusan.

Ada komponen-komponen sistem informasi Krismiaji (2005), kedelapan komponen tersebut adalah :

1. Tujuan, setiap sistem informasi dirancang untuk mencapai satu atau lebih tujuan yang memberikan arah bagi system tersebut secara keseluruhan.

2. Input, data harus dikumpulkan dan dimasukkan sebagai input ke dalam sistem. Sebagian besar input berupa data transaksi.

3. Output, informasi yang dihasilkan oleh sebuah sistem disebut output. Output dari sebuah sistem yang dimasukkan kembali kedalam sistem sebagai input disebut dengan umpan balik (feedback).

4. Penyimpanan data, data sering disimpan untuk dipakai lagi dimasa mendatang. Data yang tersimpan disini harus diperbaharui (updated) untuk menjaga keterkinian data.

5. Pemrosesan, data harus diproses untuk menghasilkan informasi dengan menggunakan komponen pemrosesan. Saat ini sebagian besar perusahaan mengolah datanya dengan menggunakan komputer, agar dapat dihasilkan informasi secara cepat dan akurat. 
6. Intruksi dan prosedur, sistem informasi tidak dapat memproses data untuk menghasilkan informasi tanpa intruksi dan prosedur rinci. Perangkat lunak (program) komputer dibuat untuk mengintruksikan komputer melakukan pengolahan data. Intruksi dan prosedur untuk para pemakai komputer biasanya dirangkum dalam sebuah buku yang disebut buku pedoman prosedur.

7. Pemakai, orang yang berinteraksi dengan sistem dan menggunakan informasi yang dihasilkan oleh sistem disebut dengan pemakai. Dalam perusahaan, pengertian pemakai termasuk didalamnya adalah karyawan yang melaksanakan dan mencatat transaksi dan karyawan yang mengelola dan mengendalikan sistem.

8. Pengamanan dan pengawasan, informasi yang dihasilkan oleh sebuah sistem informasi harus akurat, bebas dari berbagai kesalahan, dan terlindungi dari akses secara tidak sah. Untuk mencapai kualitas informasi semacam itu, maka sistem pengamanan dan pengawasan harus dibuat dan melekat pada sistem.

Sistem Informasi Akuntansi ditujukan agar penyediaan informasi keuangan bagi perusahaan memiliki tingkat keandalan dan relevan sesuai dengan kebutuhan perusahaan. Hal ini memungkinkan perusahaan dapat melihat dan menilai kinerja organisasi secara lebih transparan dan terukur. Dengan cara ini, para pemakai informasi akuntansi dapat mengambil tindakan atau kebijakan yang tepat bagi kepentingan perusahaan di masa yang akan datang.

\section{Penerapan IT dalam PT. PLN (PERSERO) Kantor Wilayah Aceh- Kota Banda Aceh}

Di era globalisasi saat ini Perkembangan Sistem Informasi (IT) sangatlah berkembang pesat, banyak sistem yang bermunculan. Sistem tersebut banyak diterapkan dalam organisasi atau perusahaanperusahaan besar. Munculnya sistem informasi (IT) ini sangat berpengaruh besar bagi kehidupan sosial dan ekonomi dalam lingkup yang luas dan sangat membantu bagi kelancaran internal dan eksternal dari sebuah perusahaan. Banyaknya sistem ini lebih mempermudah semua transaksi yang dilakukan, bagi perusahaan jasa yaitu meliputi pelaporan keuangan, database, flowchart, dan sebagainya. Kegunaan sistem ini mengikuti perkembangan zaman yang semakin modern, tetapi jangan sampai kinerja sumber daya manusia semakin menurun dengan adanya teknologi ini. Tapi semakin lebih di tingkatkan lagi, karena tanpa adanya sumber daya manusia secanggih apapun teknologi yang digunakan tidak akan bisa berguna.
Dalam hal ini, kami berfokus pada sistem informasi yang digunakan oleh PT. PLN (PERSERO) Kantor Wilayah Aceh-Kota Banda Aceh. Terdapat 4 (empat) bidang dalam perusahaan ini yaitu diantanya bidang keuangan, bidang SDM\&Umum, bidang Perencanaan, dan bidang teknik.

\section{System Application Product (SAP) Pengenalan System Application Product (SAP)}

SAP AG adalah singkatan dari System, Andwendugen, Produkte in der Detenverarbeitung, yang jika diterjemahkan ke dalam bahasa inggris menjadi System, Applications, and Product in Data Processing. SAP (System Application and Product) adalah perusahaan jerman yang merupakan perusahaan perangkat lunak terbesar di Eropa. SAP didirikan pada tahun 1972 dengan nama Systemanalise und Programmentwicklung (Sistem Analisis dan Program Pembangunan) oleh 5 mantan karyawan IBM di Mannheim, Jerman. Kantor Pusatnya di Walldorf Jerman. Perusahaan ini memperkerjakan 35.873 pekerja pada tahun 2005 .

System Application and Product (SAP) merupakan software yang dipakai oleh perusahaan untuk mendukung integrasi proses bisnis. Sistem ini berfungsi untuk memudahkan suatu organisasi dalam menjalankan kegiatan operasionalnya lebih efisien dan efektif. System Application and Product (SAP) merupakan Software Enterprise Resource Planning (ERP), yaitu suatu Tools alat IT dan manajemen untuk membantu perusahaan merencanakan dan melakukan berbagai aktivitas sehari-hari.

System Application and Product (SAP) terdiri dari sejumlah modul aplikasi yang mempunyai kemapuan mendukung semua transaksi yang perlu dilakukan suatu perusahaan dan tiap aplikasi bekerja secara berkaitan atau connect antara satu dengan lainnya, baik antar karyawan dalam satu departemen maupun antar departemen. Modul-modul ini dapat bekerja secara integrasi dan berhubungan antara satu dengan lainnya.

Di Indonesia, ada ratusan perusahaan yang mengimplementasikan sistem SAP (System Application and Product) ini. Mulai dari PT Krakatau Steel yang merupakan perusahaan pertama yang memakai sistem SAP (system Application and Product) sampai perusahaan jasa seperti Blue Bird Group juga memakai sistem yang sangat berguna ini. Modul yang digunakan pun berbeda-beda, ada yang hanya memakai untuk keperluan area tertentu seperti Financial Accounting, Sales and Distribution, Human Resources dan sebagainya sesuai kebutuhan masingmasing perusahaan.

Akibat tingginya pemakaian produk System Application and Product (SAP) di Asia Pasifik, terutama di Indonesia, kebutuhan konsultan System 
Application and Product (SAP) otomatis juga meningkat. Kebutuhan tersebut diperkirakan mencapai 60.000 hingga 80.000 konsultan secara global. Hingga tahun 2010, di Asia Tenggara sendiri, dibutuhkan sekitar 5000 hingga 8000 tenaga konsultan baru dengan kebutuhan di Indonesia kirakira 600 hingga 800 konsultan.

SAP (System Application and Product) atau dalam bahasa aslinya System Andwendungen Produkte in der Datenverarbeitung adalah suatu Software yang dikembangkan untuk mendukung suatu organisasi dalam menjalankan kegiatan operasionalnya secara labih efisien dan efektif (Marwati, 2008).

SAP (System Application and Product) terdiri dari sejumlah modul aplikasi yang mempunyai kemampuan mendukung semua transaksi yang perlu dilakukan oleh suatu perusahaan dan tiap aplikasi bekerja secara berkaitan satu dengan yang lainnya. Semua modul aplikasi di SAP (System Application and Product) dapat bekerja secara berintegrasi/terhubung dengan yang lainnya. (Marwati, 2008) System Application and Product (SAP) terdiri dari modul-modul aplikasi sebagai berikut:

1. SD-Sales and Distribution, membantu meningkatkan efisiensi kegiatan operasional berkaitan dengan proses pengelolaan customer (proses sales, shipping, dan billing).

2. MM-Material Management, membantu menjalankan proses pembelian (procurement) dan pengelolaan inventory.

3. PP-Production Planning, membantu proses perencanaan dan kontrol dari pada kegiatan produksi (manufacturing) suatu perusahaan.

4. QM-Quality Management, Membantu men-cek kualitas proses-proses di keseluruhan rantai logistik.

5. PM-Plant Management, suatu solusi untuk proses administrator dan perbaikan sistem secara teknis.

6. HR-Human Resources Management, mengintegrasikan proses-proses HR mulai dari aplikasi pendaftaran, administrasi pegawai, manajemen waktu, pembiayaan untuk perjalanan, sampai ke proses pembayaran gaji pegawai.

7. FI-Financial Accounting, mencakup standard accounting cash management (treasury), general ledger, dan konsolidasi untuk tujuan financial reporting.

8. CO-Controlling, mencakup cost accounting, mulai dari cost center accounting, cost element accounting, dan analisa profitabilitas.

9. AM-Asset Management, Membantu pengelolaan atas keseluruhan fixed assets, meliputi proses assets accounting traditional dan technical assets management, sampai ke investment controlling.

10. PS-Project System, Mengintegrasikan keseluruhan proses perencanaan project, pengerjaan dan kontrol.

Dengan mengimplementasikan System Application and Product (SAP) di suatu perusahaan akan mengintegrasikan sistem yang mengakibatkan (Marwati, 2008) antara lain :

1. Perubahan yang dilakukan pada satu modul secara otomatis akan mengupdate modul yang lainnya bila informasi yang dirubah berkaitan dengan modul tersebut. Data akan terupdate secara langsung begitu user mengimput data ke dalam sistem. Hal ini dikenal dengan istilah "read time processing".

2. Integrasi secara sistem bisa terjadi dengan syarat bahwa seluruh perusahaan harus menggunakan satu sumber data yang sama, baik untuk data customer, data product maupun data vendor.

Pada PT. PLN (PERSERO) Kantor Wilayah Aceh-Kota Banda Aceh ada tiga modul System Application and Product (SAP) yaitu Material Management (MM), Human Resource (HR), dan Financial Management (FM)

Menurut DeLone dan McLean (2003) kualitas sistem dapat diukur melalui beberapa indokator sebagai berikut:

1. Ease of use (Kemudahan Penggunaan)

Suatu sistem informasi dapat dikatakan berkualitas jika sistem tersebut dirancang untuk memenuhi kepuasan pengguna melalui kemudahan dalam menggunakan sistem informasi tersebut. Perhatian dapat diukur berdasarkan pengguna dalam menggunakan sistem informasi tersebut yang hanya memerlukan sedikit waktu untuk mempelajari sistem informasi, hal ini dikarenakan sistem informasi tersebut sederhana, mudah dipahami, dan mudah pengoperasiannya.

2. Flexibility (Fleksibilitas Sistem)

Fleksibilitas adalah kemampuan sistem informasi dalam melakukan perubahan-perubahan yang terkait dengan memenuhi kebutuhan pengguna. Pengguna akan merasa puas menggunakan sistem informasi jika sistem tersebut fleksibel dalam memenuhi kebutuhan pengguna.

3. Security (Keamanan Sistem)

Keamanan sistem dapat dilihat melalui program yang tidak dapat diubah-ubah oleh pengguna yang tidak bertanggung jawab dan juga program tidak dapat terhapus kesalahan dari pengguna. 
Hubungan System Application and Product (SAP) terhadap kepuasan pengguna software

Menurut penelitian DeLone dan McLean (2003) kualitas sistem informasi yang terdapat dalam model keberhasilan sistem informasi dapat diukur ke dalam dimensi kemudahan penggunaan (ease of use), fungsionalitas (functionality), keandalan (reliability), fleksibilitas (flexibility), kualitas data (data quality), portabilitas (portability), integrasi (integration), dan kepentingan (importance). Kualitas sistem informasi dapat terlihat dari kemampuan software untuk menghasilkan informasi yang sesuai dengan keinginan penggunanya. Sehingga dapat dikatakan bahwa jika pemakai sistem informasi percaya bahwa jika kualitas sistem informasi yang digunakan adalah baik, maka mereka akan merasa puas menggunakan sistem tersebut.

Berdasarkan penelitian diatas, maka peneliti menyimpulkan bahwa terdapat hubungan positif antara sistem informasi akuntansi (software) yaitu software akuntansi system Application and Product (SAP) terhadap kepuasan pengguna software.

$\mathrm{H}_{2}$ : Penggunaan Software Akuntansi System Application and Product (SAP) berpengaruh terhadap Kepuasan Pengguna Software Akuntansi.

\section{Kualitas Nilai Informasi Pelaporan Keuangan}

Eppler (2006) menjelaskan kualitas informasi adalah kata yang menggambarkan karakteristik informasi yang membuat informasi yang berguna bagi pengguna. Kualitas informasi merupakan kualitas output yang berupa informasi yang dihasilkan oleh sistem informasi yang digunakan. Semakin baik kualitas sistem informasi, akan semakin baik kualitas informasi yang dihasilkan dan akan semakin tepat pula keputusan yang diambil.

James A Hall (2007) menyampaikan bahwa informasi yang berkualitas tinggi adalah informasi yang dapat membantu pengguna untuk melakukan tindakan yang diharapkan.

Berdasarkan pendapat para ahli diatas peneliti menyimpulkan bahwa kualitas nilai pelaporan keuangan informasi adalah suatu informasi yang memudahkan manajemen dalam menyusun pelaporan keuangan yang mudah dipahami, relevan, dan mudah diandalkan, dan juga membantu para pemakai informasi untuk menentukan kualitas keputusan.

Indikator untuk mengukur variabel Kualitas Informasi Akuntansi, menurut McGill et al (2003), diukur dengan 5 dimensi, yaitu sebagai berikut:

1. Accuracy, berarti informasi itu harus benar, tidak ada kesalahan dan tidak menyesatkan.
2. Timelines, artinya informasi tersebut tidak boleh terlambat diterima oleh penerima.

3. Relevance, Artinya informasi tersebut harus bermanfaat bagi pemakainya.

4. Informativeness, artinya informasi harus bersifat informative artinya jelas, dan tidak mengambang.

5. Completeness, artinya informasi itu harus lengkap.

Hubungan kualitas nilai informasi pelaporan keuangan terhadap kepuasan pengguna software

Kualitas informasi merupakan kualitas output yang berupa informasi yang dihasilkan oleh sistem informasi yang digunakan. Semakin baik kualitas sistem informasi, akan semakin baik kualitas informasi yang dihasilkan dan akan semakin tepat pula keputusan yang diambil. Apabila informasi yang dihasilkan tidak berkualitas, maka akan berpengaruh negatif pada kepuasan pengguna.

Berdasarkan teori diatas, maka peneliti menyimpulkan bahwa kualitas informasi berhubungan positif dengan kepuasan pengguna akhir sistem informasi.

$\begin{array}{cccc}\mathrm{H}_{3} \quad: \quad \begin{array}{c}\text { Kualitas } \\ \text { Keuangan }\end{array} & \begin{array}{c}\text { Nilai } \\ \text { berpengaruh } \\ \text { Kepuasan } \\ \text { Akuntansi. }\end{array} & \begin{array}{c}\text { Pelaporan } \\ \text { terhadap }\end{array} \\ & & \text { Software } \\ & & \end{array}$

\section{KERANGKA KONSEPTUAL}

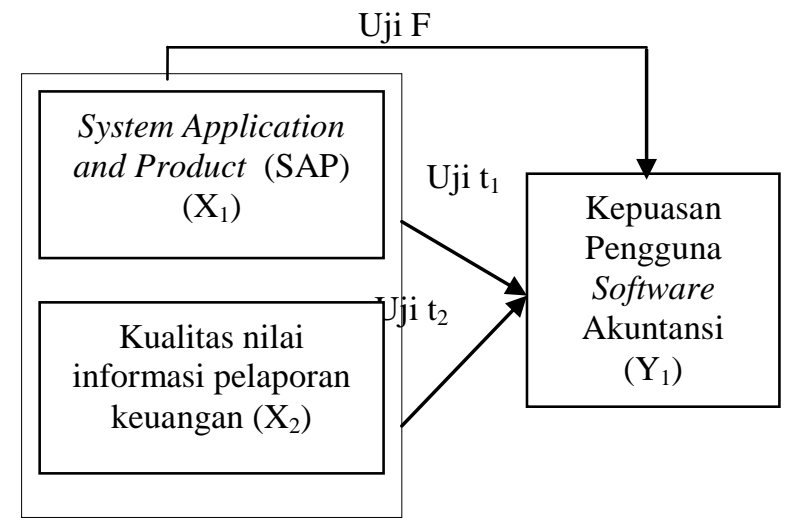

Gambar 1. Kerangka Konseptual

\section{METODE PENELITIAN}

Populasi dalam penelitian ini adalah karyawan pada bagian keuangan, bidang SDM \& Umum, bidang perencanaan dan bidang teknik. Responden pada penelitian ini meliputi karyawan pengguna software Akuntansi System Application and Product (SAP) pada PT. PLN (Persero) Kantor Wilayah Aceh-Kota Banda Aceh. 
Tabel 1. Jumlah Populasi Karyawan yang memiliki ID Di PT. PLN (Persero) Kantor Wilayah Aceh-Kota Banda Aceh

\begin{tabular}{|c|l|c|}
\hline No. & Nama Departemen & $\begin{array}{c}\text { Karyawan yang } \\
\text { memiliki ID }\end{array}$ \\
\hline 1 & Keuangan & 20 \\
\hline 2 & SDM \& Umum & 15 \\
\hline 3 & Perencanaan & 5 \\
\hline 4 & Teknik & 5 \\
\hline \multicolumn{2}{|c|}{ TOTAL } & $\mathbf{4 5}$ \\
\hline
\end{tabular}

Sumber: PT PLN (PERSERO) Kantor Wilayah Aceh- Kota Banda Aceh

Sampel yang digunakan dalam penelitian ini adalah teknik sampling jenuh. Jenis data yang digunakan dalam penelitian ini adalah berbentuk data primer. Data primer ini diperoleh berupa opini dari responden yang berbentuk Jawaban dari kuesioner yang dibagikan langsung kepada pengguna software SAP (System Application and Product) pada PT. PLN (PERSERO) Kantor Wilayah Aceh-Kota Banda Aceh, dimana kuesioner ini diberikan dan dikumpulkan langsung oleh peneliti.

Sumber data dari penelitian ini adalah data Kuesioner yang tersebar sebanyak 45. Metode analisis yang digunakan adalah analisis regresi linier berganda dengan rumus:

$$
Y=a+b_{1} X_{1}+b_{2} X_{2}+e
$$

Keterangan:

Y : Kepuasan Pengguna Software Akuntansi

a : Konstanta

$\mathrm{b}_{1}$ : Koefisien Regresi Penggunaan Software Akuntansi System Applicatiom and Product (SAP)

$\mathrm{b}_{2}$ : Koefisien Regresi Kualitas Nilai Informasi Pelaporan Keuangan

$\mathrm{X}_{1}$ :Penggunaan Software Akuntansi System Applicatiom and Product (SAP)

$\mathrm{X}_{2}$ : Kualitas Nilai Informasi Pelaporan Keuangan

e : Error Term

\section{DEFINISI OPERASIONAL DAN PENGU KURAN VARIABEL \\ Kepuasan Pengguna Software (Y)}

Variabel dependen dalam penelitian ini adalah kepuasan pengguna software akuntansi. Kepuasan pengguna software akuntansi adalah pengguna yang merasa puas terhadap kualitas sistem informasi yang digunakan dalam menghasilkan sesuatu yang dibutuhkan oleh pengguna sistem informasi.

Instrumen variabel ini terdiri dari 5 item pertanyaan yang diukur dengan 5 poin skala ordinal, yaitu Sangat tidak Setuju (1), Tidak Setuju (2), Netral (3), Setuju (4), Sangat Setuju (5).

\section{Penggunaan Software Akuntansi System Applicatiom and Product (SAP) $\left(\mathbf{X}_{1}\right)$}

System Application and Product (SAP) adalah suatu Software yang dikembangkan untuk mendukung suatu organisasi dalam menjalankan kegiatan operasionalnya secara lebih efisien dan efektif yang juga merupakan bagian dari sistem yang berhubungan langsung dengan user/pengguna sangat berperan dalam berhasil atau tidaknya suatu sistem informasi yang diimplementasikan pada suatu organisasi atau perusahaan.

Instrumen variabel ini terdiri dari 5 item pertanyaan yang diukur dengan 5 poin skala ordinal, yaitu Sangat tidak Setuju (1), Tidak Setuju (2), Netral (3), Setuju (4), Sangat Setuju (5).

\section{Kualitas Nilai Informasi Pelaporan Keuangan $\left(\mathbf{X}_{2}\right)$}

Kualitas Nilai Informasi Pelaporan Keuangan adalah suatu informasi yang memudahkan manajemen dalam menyusun pelaporan keuangan yang mudah dipahami, relevan, dan mudah diandalkan, dan juga membantu para pemakai informasi untuk menentukan kualitas keputusan.

Instrumen variabel ini terdiri dari 5 item pertanyaan yang diukur dengan 5 poin skala ordinal, yaitu Sangat tidak Setuju (1), Tidak Setuju (2), Netral (3), Setuju (4), Sangat Setuju (5).

\section{HASIL PENELITIAN DAN PEMBAHASAN}

\section{Gambaran Umum Responden}

Data dalam penelitian ini diperoleh dari penyebaran kuesioner kepada 45 orang responden yaitu karyawan pengguna software akuntansi System Application and Product (SAP) antara lain karyawan pada bagian keuangan, SDM\&Umum, perencanaan dan teknik pada PT. PLN (PERSERO) Kantor Wilayah Aceh-Kota Banda Aceh. Responden berdasarkan usia diklasifikasikan menjadi 4 bagian yaitu: antara $21-30$ tahun sebanyak 18 orang $(40,0 \%)$, antara umur 31-40 tahun sebanyak 11 orang $(24,4 \%)$, antara umur 41-50 tahun sebanyak 10 orang $(22,2 \%)$ sedangkan diatas $>51$ tahun sebanyak 6 orang $(13,3 \%)$.Maka dapat disimpulkan bahwa responden terbanyak berusia antara 21 sampai diatas 51 tahun. Responden yang berjenis kelamin laki-laki berjumlah 25 orang atau $55,6 \%$ dan responden yang berjenis kelamin perempuan berjumlah 20 orang atau $44,4 \%$. Maka dapat disimpulkan bahwa responden yang berjenis kelamin laki-laki lebih banyak dari responden yang berjenis kelamin perempuan. Pendidikan terakhir responden yaitu SMA/MA 
sebanyak 19 orang (42.2\%), DIPLOMA sebanyak 14 orang $(31.1 \%), \mathrm{S} 1$ sebanyak 12 orang $(26.7 \%)$, serta untuk S2 dan S3 adalah 0 responden, artinya responden tersebut banyak berpendidikan terakhir SMA/MA. Responden yang berdasarkan bidang yaitu untuk bidang keuangan sebanyak 20 orang (44.4\%), bidang SDM\&Umum sebanyak 15 orang (33.3\%), bidang perencanaan sebanyak 5 orang $(11.1 \%)$, dan bidang teknik sebanyak 5 orang $(11.1 \%)$. Jadi dapat disimpulkan responden yang lebih banyak pada bidang keuangan.

\section{HASIL PENGUJIAN KUALITAS DATA}

\section{Hasil Uji Validitas}

Pengujian validitas dari instrumen penelitian dilakukan dengan menghitung angka korelasional atau rhitung dari nilai jawaban tiap responden untuk tiap butir pertanyaan, kemudian dibandingkan dengan $r_{\text {tabel. }}$. Nilai $r_{\text {tabel }}=0,2940$, didapat dari jumlah DF (n) 2 , atau $45-2=43$, tingkat signifikansi $5 \%$, maka didapat $r_{\text {tabel }} 0,294$. Setiap butir pertanyaan dikatakan valid bila angka yang diperoleh dari perhitungan lebih besar atau sama dengan $\mathrm{rt}_{\text {abel }}$ (Ghozali, 2011). Berdasarkan hasil pengujian didapatkan bahwa semua pernyataan dikatakan valid, karena koefisien korelasi $\left(\mathrm{r}_{\text {hitung }}\right)>\mathrm{r}_{\text {tabel }}$.

\section{Hasil Uji Reliabilitas}

Menurut Ghozali (2013), Uji reliabilitas digunakan untuk mengukur suatu kuesioner yang merupakan indikator dari variabel. Suatu kuesioner dikatakan reliabel jika jawaban seseorang terhadap pertanyaan adalah konsisten atau stabil. Pengujian reliabilitas dalam penelitian ini adalah dengan menggunakan rumus alpha sebagai berikut:

1. Jika nilai hasil croanbach alpha $>0,60$; maka butir atau variabel tersebut reliabel.
2. Jika nilai hasil croanbach alpha $<0,60$; maka butir atau variabel tersebut tidak reliabel.

Untuk mengetahui hasil uji reliabilitas dalam penelitian ini, maka dapat dilihat dari tabel di bawah ini:

Tabel 2. Hasil Pengujian Reliabelitas

\begin{tabular}{|l|l|l|l|}
\hline Variabel & Alpha & Batasan & Keterangan \\
\hline Kepuasan & & & \\
Pengguna & 0,790 & 0,60 & Reliabel \\
$\begin{array}{l}\text { Software } \\
\text { Akuntansi (Y) }\end{array}$ & & & \\
\hline $\begin{array}{l}\text { Penggunaan } \\
\text { Software }\end{array}$ & & & \\
Akuntansi & & & \\
System & 0,829 & 0,60 & Reliabel \\
Application and & & & \\
Product (SAP) & & & \\
(X) & & & \\
\hline Kualitas Nilai & & & Reliabel \\
Informasi & 0,791 & 0,60 & \\
Pelaporan & & & \\
Keuangan (X & & \\
\hline Sumber: Data Prim & & & \\
\hline
\end{tabular}

Sumber: Data Primer, 2018 (diolah)

\section{HASIL UJI ASUMSI KLASIK Hasil Uji Normalitas}

Uji normalitas bertujuan untuk menguji apakah dalam suatu model regresi linear berganda variabel bebas dan variabel terikat keduanya mempunyai distribusi normal atau tidak. Model regresi yang baik adalah memiliki distribusi data normal atau mendekati normal. Uji normalitas dapat diketahui dengan melihat normal probability plot. Distribusi normal akan membentuk satu garis lurus diagonal dan ploting data residual akan dibandingkan dengan garis diagonal. Jika distribusi data residual normal, maka titik-titik yang menggambarkan data akan mengikuti garis diagonalnya.

Dependent Variable: Kepuasan pengguna sı

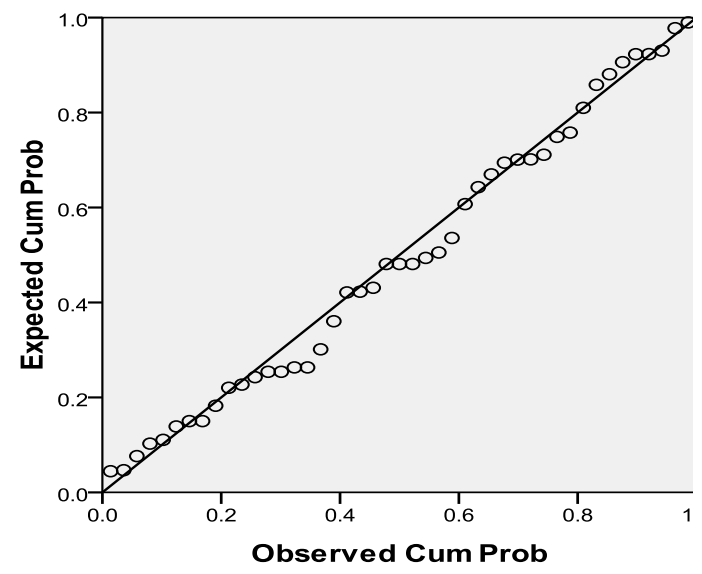




\section{Gambar 2. Normal P-P Plot Regression}

\section{Hasil Uji Kolmogorov Smirnov}

Uji kolmogorov-smirnov merupakan pengujian ststistis non-parametric yang paling mendar dan paling banyak digunakan, uji ini digunakan untuk menguji "goodness of fit" antar distribusi sampel dan distibusi lainnya.

Tabel 3. Uji Kolmogorov Smirnov One-Sample Kolmogorov-Smirnov Test

\begin{tabular}{|ll|r|}
\hline & & $\begin{array}{c}\text { Unstandardized } \\
\text { Residual }\end{array}$ \\
\hline $\mathrm{N}$ & Mean & 45 \\
& Std. & .0000000 \\
& Deviation & 2.24760600 \\
Most Extreme Differences & Absolute & \\
& Positive & .097 \\
& Negative & .097 \\
Kolmogorov-Smirnov Z & & -.045 \\
Asymp. Sig. (2-tailed) & & .652 \\
\end{tabular}

a. Test distribution is Normal.

b. Calculated from data.

Berdasarkan Tabel one-sample kolmogorovsmirnov test, menunjukkan bahwa nilai asymp. Sig. (2-tailed) $>0,05$ maka data berdistribusi normal.

\section{Hasil Uji Multikolinieritas}

Uji multikolinearitas bertujuan untuk menguji apakah dalam model regresi ditemukan adanya korelasi antara variabel bebas (independen). Untuk mendeteksi ada tidaknya gejala multikolinearitas antara variabel independen, dapat dilihat dari nilai tolerance dan variance inflation factor (VIF). Kriteria pengujian menunjukkan tidak ada satu variabel yang memiliki nilai VIF kurang dari 10 dan nilai tolerance juga menunjukkan tidak satu variabel bebas yang memiliki nilai tolerance lebih dari $10 \%$. Hal itu menandakan bahwa model regresi yang dihasilkan tidak terjadi multikolinieritas.

Tabel 4. Uji Multikolinieritas

\begin{tabular}{|l|l|l|l|}
\hline Variabel & \multicolumn{2}{|c|}{$\begin{array}{c}\text { collinearity } \\
\text { Statistic }\end{array}$} & \multirow{2}{*}{ Keterangan } \\
\cline { 2 - 3 } & Tolerance & VIF & \\
\hline $\mathrm{X}_{1}$ & 0,469 & 2,133 & $\begin{array}{l}\text { Tidak ada } \\
\text { multikolinieritas }\end{array}$ \\
\hline $\mathrm{X}_{2}$ & 0,469 & 2,133 & $\begin{array}{l}\text { Tidak ada } \\
\text { multikolinieritas }\end{array}$ \\
\hline
\end{tabular}

Sumber: Data Primer, 2018 (diolah)

\section{Hasil Analisis Regresi Linear Berganda}

Penelitian ini bertujuan untuk mengetahui pengaruh Pengaruh Self Assessment System, Money Ethics, dan Teknologi dan Informasi Perpajakan Terhadap Persepsi Wajib Pajak Badan Mengenai Tax Evasion. Hasil analisis linear berganda dengan program SPSS versi 17.0 dapat dilihat pada tabel 4 . sebagai berikut.

Tabel 5. Hasil Analisis Regresi Linear Berganda

Coefficients $^{\mathrm{a}}$

\begin{tabular}{|c|c|c|c|c|c|c|c|c|}
\hline \multirow[b]{2}{*}{ Model } & & \multicolumn{2}{|c|}{$\begin{array}{l}\text { Unstandardized } \\
\text { Coefficients }\end{array}$} & \multirow{2}{*}{\begin{tabular}{|l}
$\begin{array}{l}\text { Standardize } \\
\mathrm{d} \\
\text { Coefficients }\end{array}$ \\
Beta \\
\end{tabular}} & \multirow[b]{2}{*}{$\mathrm{T}$} & \multirow[b]{2}{*}{ Sig. } & \multicolumn{2}{|c|}{ Collinearity Statistics } \\
\hline & & B & Std. Error & & & & Tolerance & VIF \\
\hline 1 & (Constant) & 2.523 & 2.183 & & 1.156 & .254 & & \\
\hline & $\mathrm{X} 1$ & .570 & .128 & .378 & 4.445 & .000 & .469 & 2.133 \\
\hline & $\mathrm{X} 2$ & .935 & .129 & .614 & 7.217 & .000 & .469 & 2.133 \\
\hline
\end{tabular}

Berdasarkan tabel 4. di atas, maka dapat dibentuk persamaan regresi linear berganda sebagai berikut:

hasil analisis menunjukkan bahwa: 
a. Konstanta $(\alpha)$ sebesar 2, 523, hal ini menyatakan bahwa jika variabel $\mathrm{X}_{1}$ dan $\mathrm{X}_{2}$ tidak terjadi peningkatan atau 0 , maka tingkat kepuasan pengguna software akuntansi adalah sebesar 2,523

b. Koefisien Pertama yaitu Penggunaan Software Akuntansi System Application and Product (SAP) $\left(\mathrm{X}_{1}\right)$ sebesar 0,570 , hal ini menunjukkan bahwa jika terjadi peningkatan Penggunaan Software Akuntansi System Application and Product (SAP) sebesar 1, maka akan meningkatkan kepuasan pengguna software akuntansi sebesar 0,570.

c. Koefisien Kedua yaitu Kualitas Nilai Informasi Pelaporan Keuangan $\left(\mathrm{X}_{2}\right)$ sebesar 0,935, hal ini menunjukkan bahwa jika terjadi peningkatan Kualitas Nilai Informasi Pelaporan Keuangan sebesar 1, maka akan meningkatkan kepuasan pengguna software akuntansi sebesar 0,935.

\section{Hasil Pengujian Hipotesis dan Pembahasan Hasil Uji t \\ Uji $\mathrm{t}$ dilakukan adalah untuk mengetahui pengaruh variabel independen terhadap dependen secara parsial. Hasil uji t dapat dilihat pada tabel 5 berikut}

Tabel 6. Hasil Uji t Coefficients $^{\text {a }}$

\begin{tabular}{|c|c|c|c|c|c|c|c|}
\hline \multirow[b]{2}{*}{ Model } & \multicolumn{2}{|c|}{$\begin{array}{l}\text { Unstandardized } \\
\text { Coefficients }\end{array}$} & \multirow{2}{*}{\begin{tabular}{|c}
$\begin{array}{c}\text { Standardized } \\
\text { Coefficients }\end{array}$ \\
Beta \\
\end{tabular}} & \multirow[b]{2}{*}{$\mathrm{t}$} & \multirow[b]{2}{*}{ Sig. } & \multicolumn{2}{|c|}{ Collinearity Statistics } \\
\hline & $\mathrm{B}$ & Std. Error & & & & Tolerance & VIF \\
\hline $1 \quad$ (Constant) & 2.523 & 2.183 & & 1.156 & .254 & & \\
\hline $\mathrm{X} 1$ & .570 & .128 & .378 & 4.445 & .000 & .469 & 2.133 \\
\hline $\mathrm{X} 2$ & .935 & .129 & .614 & 7.217 & .000 & .469 & 2.133 \\
\hline
\end{tabular}

a. Dependent Variable: Y

\section{$\mathrm{H}_{1}$ : Penggunaan Software Akuntansi System Applications and Product (SAP) berpengaruh terhadap Kepuasan Pengguna Software Akuntansi.}

Secara parsial (uji t) yang di peroleh dari nilai $\mathrm{T}_{\text {hitung }}$ pada persamaan regresi linear berganda menyatakan bahwa Penggunaan Software Akuntansi System Application and Product (SAP) berpengaruh signifikan (nyata) terhadap Kepuasan Pengguna Software Akuntansi, dikarenakan $\mathrm{T}_{\text {hitung }}$ sebesar 4,445 dan $\mathrm{T}_{\text {tabel (n-2, 5\% uji dua pihak) }}=2,016$ di mana $\mathrm{T}_{\text {hitung }}>$ $\mathrm{T}_{\text {tabel }}$ dengan nilai signifikansi 0,00 di bawah 0,05 . Sehingga hipotesis pertama $\left(\mathrm{H}_{1}\right)$ diterima.

Hal ini menunjukkan bahwa secara statistik Penggunaan Software Akuntansi System Application and Product (SAP) berpengaruh signifikan terhadap Kepuasan Pengguna Software Akuntansi pada PT. PLN (PERSERO) Kantor Wilayah Aceh-Kota Banda Aceh.

Kualitas sistem informasi dapat dilihat dari kemampuan software untuk menghasilkan informasi yang sesuai dengan keinginan penggunanya. Sehingga dapat dikatakan bahwa jika pemakai sistem informasi percaya bahwa jika kualitas informasi yang digunakan adalah baik, maka semakin baik juga kepuasan pengguna software. Sebagai contoh, software akuntansi yang digunakan pada PT. PLN (PERSERO) Kantor Wilayah Aceh-Kota Banda Aceh adalah software System Application and Product (SAP), hendaknya software ini menghasilkan
$\mathrm{T}_{\text {table: }}: 2,016$

informasi laporan keuangan yang berguna bagi pengambil keputusan, sehingga semakin tinggi tingkat kepuaasan pengguna software akuntansi.

Penelitian ini sejalan dengan penelitian Purnamasari (2012) yang menyimpulkan bahwa Kualitas Sistem Informasi Akuntansi berpengaruh terhadap Kepuasan Pengguna Akhir, dimana Kualitas Sistem Informasi Akuntansi yang tinggi akan meningkatkan Kepuasan Pengguna Akhir. Penelitian ini juga mendukung penelitian DeLone dan McLean (2003) menyatakan kualitas sistem informasi yang terdapat dalam model keberhasilan sistem informasi dapat diukur ke dalam dimensi kemudahan penggunaan (ease of use), fungsionalitas (functionality), keandalan (reliability), fleksibilitas (flexibility), kualitas data (data quality), portabilitas (portability), integrasi (integration), dan kepentingan (importance). Kualitas sistem informasi dapat terlihat dari kemampuan software untuk menghasilkan informasi yang sesuai dengan keinginan penggunanya.

\section{$\mathrm{H}_{2}$ : Kualitas Nilai Informasi Pelaporan Keuangan berpengaruh terhadap Kepuasan Pengguna Software Akuntansi.}

Secara Parsial (uji t) yang di peroleh dari nilai $\mathrm{T}_{\text {hitung }}$ pada persamaan regresi linear berganda menyatakan bahwa Kualitas Nilai Informasi Pelaporan Keuangan berpengaruh signifikan (nyata) terhadap Kepuasan Pengguna Software Akuntansi, dikarenakan $\mathrm{T}_{\text {hitung }}$ sebesar 7,217 dan $\mathrm{T}_{\text {tabel (n-2, 5\% uji dua }}$ 
pihak) $=2,016$ di mana $\mathrm{T}_{\text {hitung }}>\mathrm{T}_{\text {tabel }}$ dengan nilai signifikansi 0,00 di bawah 0,05. Sehingga hipotesis kedua $\left(\mathrm{H}_{2}\right)$ diterima.

Hal ini membuktikan bahwa Kualitas Nilai Informasi Pelaporan Keuangan berpengaruh signifikan terhadap Kepuasan Pengguna Software Akuntansi pada PT. PLN (PERSERO) Kantor Wilayah Aceh-Kota Banda Aceh.

Kualitas informasi merupakan kualitas dari output yang berupa informasi yang dihasilkan oleh sistem informasi yang digunakan. Semakin baik informasi yang dihasilkan maka semakin tinggi kepuasan pengguna software akuntansi.. Sebagai contoh, PT. PLN (PERSERO) Kantor Wilayah AcehKota Banda Aceh menggunakan software akuntansi System Application and Product (SAP) untuk menghasilkan informasi yang berupa Laporan Keuangan, jadi sebaiknya informasi dari laporan keuangan yang digunakan oleh PT. PLN (PERSERO) mampu menyediakan informasi yang dibutuhkan penggunanya.

Hasil Uji F
Penelitian ini sejalan dengan penelitian kowanda, dkk (2016) yang menyimpulkan bahwa Kualitas Informasi berpengaruh positif signifikan terhadap pengguna akhir software. Hal ini dapat dilihat dari segi akurasi (accuracy), ketepatan waktu (timeliness), kelengkapan (completeness), relevansi (relevance), dan konsistensi (consistency) yang terdapat dalam dimensi kualitas informasi dirasakan secara nyata dari output berupa laporan keuangan yang dihasilkan. Semakin tinggi kualitas informasi yang dihasilkan oleh software akan semakin meningkatkan kepuasan penggunanya.

Tabel 7. Hasil Uji F

ANOVA $^{b}$

\begin{tabular}{|rr|r|r|r|c|c|}
\hline Model & Sum of Squares & Df & Mean Square & F & Sig. \\
\hline 1 & Regression & 338.924 & 2 & 69.462 & 26.498 & $.000^{\mathrm{a}}$ \\
Residual & 222.276 & 42 & 5.292 & & \\
Total & 561.200 & 44 & & & \\
\hline
\end{tabular}

a. Predictors: (Constant), Kualitas Nilai Informasi Laporan Keuangan, Penggunaan Software sistem application and Product (SAP)

b. Dependent Variable: Kepuasan pengguna software

Sumber: Data Primer, 2018 (diolah)

\section{$\mathrm{H}_{3}$ : Penggunaan Software Akuntansi System Applications and Product (SAP) dan Kualitas Nilai Informasi Pelaporan Keuangan berpengaruh terhadap Kepuasan Pengguna Software Akuntansi.}

Berdasarkan Tabel 7 , di atas dapat dilihat bahwa nilai $F_{\text {hitung }}$ sebesar 26 , 498, sedangkan $F_{\text {tabel }}$ pada tingkat kepercayaan $100 \%$ diperoleh $\mathrm{F}_{\text {tabel(df2 }=\mathrm{n}-\mathrm{k}-}$ ${ }_{1,5 \%)}=3,23$, atau dengan kata lain $F_{\text {hitung }}>F_{\text {tabel }}$, dan juga dapat dilihat dari sig $0,000<0,05$. Pengujian hipotesis dengan uji $\mathrm{F}$ dilakukan dengan membandingkan antara $F_{\text {hitung }}$ dengan $F_{\text {tabel }}$, dan nilai signifikansinya. Dengan demikian berarti secara simultan variabel Penggunaan Software Akuntansi
System Application and Product (SAP) $\left(\mathrm{X}_{1}\right)$, dan Kualitas Nilai Informasi Pelaporan Keuangan $\left(\mathrm{X}_{2}\right)$, berpengaruh secara signifikan terhadap Kepuasan Pengguna Software Akuntansi (Y) pada PT. PLN (PERSERO) Kantor Wilayah Aceh-Kota Banda Aceh. Sehingga hipotesis ketiga $\left(\mathrm{H}_{3}\right)$ diterima.

Hal ini membuktikan bahwa pengaruh penggunaan Software Akuntansi System Application and Product (SAP) dan Kualitas Nilai Informasi Pelaporan Keuangan secara simultan berpengaruh signifikan Terhadap Kepuasan Pengguna Software Akuntansi pada PT. PLN (PERSERO) Kantor Wilayah Aceh-Kota Banda Aceh.

Informasi yang digunakan disini adalah Laporan Keuangan yang digunakan oleh pihak internal dan eksternal perusahaan. Sebaiknya software Akuntansi System Application and Product (SAP) yang digunakan oleh PT. PLN (PERSERO) mampu menyediakan informasi yang dibutuhkan, karena semakin berkualitas laporan keuangan yang 
dihasilkan, semakin tepat keputusan yang akan diambil perusahaan dan semakin tinggi tingkat kepuasan pengguna software Akuntansi.

Penelitian ini mendukung penelitian Purnamasari (2012) yang menyatakan bahwa Kualitas Sistem Infromasi Akuntansi berpengaruh terhadap Kepuasan Pengguna Akhir dan implikasinya pada kepuasan pengguna akhir, agar dapat meningkatkan kepuasan pengguna akhir maka harus meningkatnya kualitas informasi akuntansi, dan cara untuk meningkatkan kualitas informasi akuntansi yaitu dengan meningkatkan kualitas sistem informasi akuntansinya.

\section{SIMPULAN DAN SARAN}

\section{Simpulan}

Penelitian ini bertujuan untuk mengetahui pengaruh penggunaan software akuntansi System Application and Product (SAP) dan kualitas nilai informasi pelaporan keuangan terhadap kepuasan pengguna software akuntansi pada PT. PLN (PERSERO) Kantor Wilayah Aceh-Kota Banda Aceh. Dengan melakukan pengumpulan data dari kuesioner yang disebarkan pada pengguna software di bidang keuangan, SDM\&Umum, Perencanaa, dan Teknik pada PT. PLN (PERSERO) Kantor Wilayah Aceh-Kota Banda Aceh, serta menggunakan metode penelitian regresi linier berganda, data diolah dengan menggunakan software SPSS 17, dan didapat hasil sebagai berikut:

1. Hal ini menunjukkan bahwa Penggunaan Software Akuntansi System Application and Product (SAP) berpengaruh signifikan (nyata) terhadap Kepuasan Pengguna Software Akuntansi (Studi kasus pada PT.PLN (PERSERO) Kantor Wilayah Aceh - Kota Banda Aceh.

2. Hal ini menunjukkan bahwa Kualitas Nilai Informasi Pelaporan Keuangan berpengaruh signifikan (nyata) terhadap Kepuasan Pengguna Software Akuntansi (Studi kasus pada PT.PLN (PERSERO) Kantor Wilayah Aceh - Kota Banda Aceh.

3. Hal ini menunjukkan bahwa secara simultan variabel Penggunaan Software Akuntansi System Application and Product (SAP) $\left(\mathrm{X}_{1}\right)$, dan Kualitas Nilai Informasi Pelaporan Keuangan $\left(\mathrm{X}_{2}\right)$, berpengaruh secara signifikan terhadap Kepuasan Pengguna Software Akuntansi (Y) pada PT. PLN (PERSERO) Kantor Wilayah Aceh-Kota Banda Aceh.

\section{Saran}

1. Untuk perusahaan PT. PLN (PERSERO) Kantor Wilayah Aceh-Kota Banda Aceh, software
Akuntansi System Application and Product (SAP) ini, dari hasil analisis, dengan kemampuan software ini dalam meningkatkan kinerja karyawan dan kecepatan pemrosesan data, akan terus meningkatkan kualitas nilai informasi pelaporan keuangan dan kepuasan pengguna, sehinnga perusahaan dapat terus meningkatkan jumlah pemakai dengan memberikan pelatihan bagi karyawan yang belum memakai software tersebut.

2. Penelitian ini hanya menguji pengaruh penggunaan software Akuntansi System Application and product (SAP) dan kualitas nilai informasi pelaporan keuangan terhadap kepuasan pengguna software akuntansi. Sehingga tidak dapat menjelaskan faktor-faktor lain atau variabel lain yang mempengaruhi kepuasan pengguna software,seperti Perceived usefulnes atau variabel lainnya yang dapat mempengaruhi kepuasan pengguna software akuntansi.

3. Menggunakan alat uji yang lebih baik lagi agar menghasilkan data yang akurat.

\section{KEPUSTAKAAN}

Ariesta, Fadila. (2013). Pengaruh Kualitas Sumber daya Manusia, Pemanfaatan Teknologi Informasi, Dan Pengendalian Intern Akuntansi Terhadap Nilai Informasi Pelaporan Keuangan Pemerintah Daerah. Jurnal Ekonomi Akuntansi Universitas Negeri Padang.

Bergensen, Bard M. 2008. User Satisfaction and Influencing Issue. Artikel. Melalui (www.Iu.hio.no/rm/bard.pdf) diakses tanggal 15 Nopember 2013.

Bodnar, George H dan William S Hopwood. 2004. Sistem Informasi Akuntansi. Penerjemah Julianto Agung Saputra. Yogyakarta: Andi.

DeLone, W. H. dan Ephraim R. McLean. 2003. The DeLone and McLean Model of Information Systems Success : A Ten-Year Update. Journal of Management Information Systems : Spring vol.19. No. 4, pp.9-30

Eppler, M.J. (2006). Managing Information Quality: Increasing the Value of Information in Knowledge-Intensive Products and Processes. Germany: Springer BerlinHeidelberg

Fahmi, Muhibban. (2014). Pengaruh Penggunan Software Akuntansi System Application and 
Product terhadap kualitas nilai informasi pelaporan keuangan dan kepuasan pengguna software akuntansi. Jurnal. Program Studi Akuntansi universitas Unsyiah. Banda Aceh.

Fardinal. 2013. The Quality of Accounting Information and The Accounting Information System through The Internal Control Systems: A Study on Ministry and State Agencies of The Republic of Indonesia. Research Journal of Finance and Accounting, 4(6).

Febryanty. (2009). Evaluasi Penerapan Sistem Informasi Akuntansi pada Sistem Pengajuan dan Persetujuan Kredit pada PT. BPR. Jurnal Akuntansi. Universitas Gunadarma Jakarta.

Ghozali, Imam. (2013). Aplikasi Analisis Multivariate dengan Program IBM SPSS 21 Update PLS Regresi. Edisi 7. Semarang: Badan Penerbit Universitas Diponegoro.

Gunarso Avianto dan Prihantoro. (2012). Analisis Sistem Informasi Akuntansi Dan Sistem Pengendalian Internal Perkreditan Pada Pt. Btpn Mur (Mitra Usaha Rakyat) Tbk Cabang Pamanukan. Jurusan Akuntansi, Fakultas Ekonomi, Universitas Gunadarma.

Hall, James A. (2008). Accounting Information Systems. $6^{\text {th }}$ Edition. Natorp Boulevard Mason. OH: Cengage Learning.

http:// rendhart.blogspot.co.id/2015/11/uji-koefisiendeterminasi-r-kuadrat-r2.html di akses 20 November 2015

http://umntalaud.wordpress.com/2013/11/21enterpric e-resource-planning-pt-pln-persero-distribusibali di akses 21 November 2013

http://www.bambanghariyanto.com/2013/10/karateris tik-laporan-keuangan menurut-psak.html. di akses 15 Oktober 2013

Indriani, mirna dan Reza Adryan. (2009). Kualitas Sistem Informasi Dan Kepuasan Pengguna Sistem Informasi Perguruan Tinggi Universitas Syiah Kuala. Jurnal Telaah \& Riset Akuntansi Vol.2 No.2 Hal. 79-92.
Insap Santoso. (2009). Interaksi Manusia dan Komputer, Edisi 2. Yogyakarta: CV Andi Offset.

Kitcharoen, Siriwan. (2007). Importance-Perfomace Analysis On Information technology ApplicationsIn Higher Education Institution In Thailand. ABAC Journal Vol. 27, No.2.

Kowanda. Dionysia., Muhammad Firdaus dan Rowland Bismark Fernando Pasaribu. (2016). Determinan kepuasan pengguna akhir aplikasi ERP free open source adempiere pada usaha Kecil menengah: studi kasus pada Ukm blessings. Jurnal Riset Akuntansi dan Keuangan Vol 12 Nomor 2 Hal. 111-129.

Krismiaji. (2002). Sistem Informasi Akuntansi. Yogyakarta : UPP AMP YKPN.

Lee, H. S., dan Kim, J.W. (2010). Student User Satisfaction with Web-Based Information Systems in Korea University. International Journal of Business and Management, 62.

Mahfudh, Ghammal Frizza. (2009). Pengaruh penggunaan software akuntansi System Application and product (SAP) Terhadap Kualitas Nilai Pelaporan Keuangan pada Perusahaan PT. NGL. Co di Lhokseumawe. Jurnal. Fakultas Ekonomi Universitas Syiah Kuala.

Marwati, Fithri. (2008). System Application and Product in data Processing at PT Frisian Flag Indonesia. Melalui (http://Fithrimarwati.wordpress.com. Diakses tanggal 17 November 2013.

McGill, Tanya, Hobbs, Valerie \& Klobas, Jane. (2003). User-Developed Application and Information System Success: a Test of DeLone and McLean's Model. Information Resource Management Journal, 16(1): 24-45, Jan-Mar 2003.

Mutiara Amalia, Syara dan Dudi Pratomo. (2016). Pengaruh Kualitas Sistem Informasi, Kualitas Informasi, Dan Perceived Usefulness Terhadap Kepuasan Pengguna Sistem Informasi Akuntansi. Jurnal eProceeding of management Vol 3 Nomor 2 page 1516. 
O’Brien, James A. 2006. Pengantar Sistem Informasi: Perspektif Bisnis dan Manajerial. Edisi 12. Terjemahan Dewi dan Deny. 2006. Jakarta: Salemba Empat

Purnamasari, Ratih. (2012). Pengaruh kualitas sistem informasi akuntansi terhadap kualitas informasi akuntansi dan implikasinya pada kepuasan pengguna akhir. Jurnal Ekonomi-Akuntansi Universitas Komputer Indonesia.

Romney, Marshall B. and Paul John Steinbart. (2009). Accounting Information System. Jakarta: Salemba Empat.

Kumala, Diyana., Jaluanto. Analisis Kualitas Informasi Akuntansi Keuangan Pada PT.PLN (Persero) Wilayah Jawa Tengah. Jurnal Ilmiah UNTAG Semarang.

Sugiyono, Prof.Dr. (2012). Metode Penelitian Bisnis. Penerbit Alfabeta. Bandung.

Sulistyoningsih. 2006. Analisis Kualitas Informasi Akuntansi. Jurnal Sistem Informasi Akuntansi Vol.5 no 3 hal 69.

Sunyoto, Danang. 2013. Analisis Data Ekonomi dengan Menggunakan SPSS. Jakarta: PT. Indeks

Supriyatna, Dicky, dan Jin, Fung, Tjhai., (2006). Analisis Pengaruh Kepuasan Pengguna Public Computer Terhadap Efisiensi dan Efektivitas Mahasiswa Trisakti School of Management. Jurnal Bisnis dan Akuntansi. Vol.8, No.2, Agustus 2006, 111-134.

Surtardji dan Sri Ismi Mauidyah. (2006). Analisis beberapa faktor yang berpengaruh pada kepuasan pengguna Perpustakaan: Studi kasus diperpustakaan balai penelitian tanaman kacang-kacangan dan umbi-umbian. Jurnal Perpustakaan Pertanian. Vol.15, No.2.

Wati, Kadek Desiana., Nyoman Trisna Herawati., Ni Kadek Sinarwati. (2014). Pengaruh Kompetensi Sdm, Penerapan Sap, Dan Sistem Akuntansi Keuangan Daerah Terhadap Kualitas Laporan Keuangan Daerah. Jurnal S1 Ak Vol 2 Nomor 1

Zunaidi, Makhbub, Dwi Eko Waluyo, dan Dewi Agustini. (2011). Analisis Pengaruh
Akurasi, Ketepatan Waktu dan Relevansi Informasi Terhadap Kepuasan Pemakai Sistem Informasi ATEMIS On Web di PT TELKOM MSC Area IV Jawa Tengah dan DIY. Jurnal Seminar Nasional Teknologi Informasi \& Komunikasi Terapan. Vol.1, No.1.

54-Unsur-karakteristik-sia_2.pdf-Adobe Reader DC. Diakses tanggal 01 maret 2018. 